Çukurova Üniversitesi Mühendislik Mimarlık Fakültesi Dergisi, 31(1), 241-253 ss., Haziran 2016

Çukurova University Journal of the Faculty of Engineering and Architecture, 31(1), pp. 241-253 June 2016

\title{
İnşaat Sektörü Proje Yöneticilerinin Algılanan Liderlik Stilleri
}

\author{
Gülden GÜMÜŞBURUN AYALP*1, Mehmet Can KERETLí1 \\ ${ }^{1}$ Zirve Üniversitesi, Mimarlık ve Tasarım Fakültesi, Mimarlık Bölümü, Gaziantep
}

Geliş tarihi: 26.01.2016 Kabul tarihi: 16.05.2016

\section{Özet}

Tüm sektörlerde olduğu gibi inşaat sektöründe de bir projenin başarılı olabilmesi için, yöneticinin sahip olduğu liderlik özellikleri büyük rol oynamaktadır. Çünkü liderin, çalışanların tutum, davranış ve başarı düzeylerini önemli ölçüde etkilemesi organizasyonların performansını da etkilemektedir. Bu nedenle, bu çalışmada Türk inşaat sektöründe faaliyet gösteren proje yöneticilerinin liderlik stillerinin belirlenmesi amaçlanmıştır. Yöneticilerin kendi ile ilgili değerlendirmeleri tarafsız bir şekilde yapamayacağı düşünülerek, sektörde iş gören mimar ve inşaat mühendislerinin görüşlerine başvurulmuştur. $\mathrm{Bu}$ çerçevede, "Çok Faktörlü Liderlik Anketi (MLQ-5X)" kullanılarak veri toplanmıştır. Elde edilen veriler ile proje yöneticilerinin liderlik stillerinin belirlenmesine ek olarak, yöneticilerin liderlik stilleri ile cinsiyet, meslek ve deneyim süresi arasında ilişki olup olmadığı araştırılmıştır.

Anahtar Kelimeler: Liderlik stilleri, İnşaat sektörü, Çok faktörlü liderlik anketi, Proje ve yapım yönetimi

\section{Perceived Leadership Styles of Turkish Construction Managers}

\begin{abstract}
The leadership properties of a manager play a vital role at the success of project in the construction sector like the other professional industries. Performance of the organizations are effected by the reason of leader effect the employees' behavior and success. Therefore, it is aimed to determine the leadership styles of construction managers at Turkey. The data were obtained from architects and civil engineers who are working as an employee at construction sector by the reason of managers cannot evaluate themselves objectively. Within this framework, data were obtained by using "Multifactor Leadership Questionnaire (MLQ-5X)". As a conclusion, leadership styles of construction managers determined and the relationship between their leadership styles and gender, occupation and experience were examined.
\end{abstract}

Keywords: Leadership styles, Construction industry, Multi factor leadership questionnaire, Construction management.

\footnotetext{
* Yazışmaların yapılacağı yazar: Gülden GÜMÜŞBURUN AYALP, Zirve Üniversitesi, Mimarlık ve Tasarım Fakültesi, Mimarlı Bölümü, Gaziantep. gldngumusburun@hotmail.com
} 


\section{GíRiș}

İnsanlar, topluluk halinde yaşayan sosyal nitelikli canlılar oldukları için, grup oluşturma gereksinimi duyarlar. İnsanların, oluşturdukları bu grupları yönetecek ve hedeflerine götürecek liderlere gereksinim duymaları, grupların ortak bir amaç etrafında ve birlik içinde hareket edebilmesi için hiyerarşik bağlılığa gereksinim duymalarından kaynaklanır. Belirli amaçlara yönelmiş bulunan bu kişilerin, hedeflere doğru yönlendirilmesi, ayrı bir beceri ve ikna yeteneği gerektirir [1].

Kişisel amaçlar veya grup amaçlarını gerçekleştirmek üzere, bir kimsenin başkalarının faaliyetlerini etkilemesi ve yönlendirmesi süreci olarak tanımlanan liderlik kavramı, lider, izleyiciler ve koşullardan oluşur. Lider, başkalarını belirli bir amaç doğrultusunda davranmaya sevk ederek etkileyen kişidir [2]. Etkili bir liderlik için takım ruhu yaratmak, ekip üyelerinin kişisel hedefleri ile ekibin ortak hedeflerinin çakışmasının sağlanması gerekir [3]. Liderlerin, çalışanlarıyla etkili ilişkiler kurabilmeyi sağlayacak üst düzeyde liderlik özelliklerine sahip olmaları, başarılı olmaları için önemli bir koşuldur [4]. Lider; hitap ettiği grubun yapısına, kültür seviyesi, yaş ve deneyimlerine göre liderlik davranışlarını belirlemek durumundadır [1]. Çünkü liderin, çalışanların tutum, davranış ve başarı düzeylerini önemli ölçüde etkilemesi organizasyonların performansını da etkilemektedir.

İnşaat sektörünü diğer endüstrilerden ayıran farklı özellikler mevcuttur [5]. Bu özellikler a) proje bazlı bir endüstri olması, b) sözleşmeye dayalı düzenlemeler gerektirmesi, c) proje yaşam döngüsü sürecine sahip olması ve, d) çevresel faktörlerdir. Adı geçen özellikler, inşaat sektöründeki yöneticilerin liderlik özelliklerini ve liderlik stillerini doğrudan etkilemektedir.

Literatürde, kalıcı organizasyon yapıları olan endüstrilerdeki liderlik stilleri ile ilgili yapılmış pek çok çalışma bulunmaktadır [6-9]. Son yirmibeş yıldan bu yana ise inşaat sektöründe liderlik konusu araştırmacılar tarafından dikkat çekmekte olup, bu konuda yapılan çalışmaların sayısı hızla artmaktadır [10-18]. Çünkü yapılan çalışmalar göstermektedir ki liderin tutum ve davranışları ilk kademede çalışanları daha sonra da içinde bulunulan örgütü doğrudan etkilemektedir. Belirtilen nedenlerle bu çalışmada Türk inşaat sektöründe faaliyet gösteren proje yöneticilerinin liderlik stillerinin belirlenmesi amaçlanmıştır. $\mathrm{Bu}$ amaçla, yöneticilerin liderlik stillerinden en çok etkilenen iş gören mimar ve inşaat mühendislerinden "Çok Faktörlü Liderlik Anketi (MLQ-5X)" kullanılarak veri toplanmıştır. Yöneticilerin liderlik stillerinin belirlenmesine ek olarak, liderlik stilleri ile cinsiyet, meslek, deneyim süresi arasında ilişki olup olmadığ1 araştırılmıştır.

\section{2. İNSAAT SEKTÖRÜNDE LIDERLIIK STILLLERI}

Yapı üretimi, disiplinler arası işbirliği ile gerçekleștirilen bir üretim şekli olup, eşgüdümlü ekip çalışması gerektiren bir süreçtir. Bu üretim sürecinde inşaat işlerinin beklenen kalite, maliyet ve sürede tamamlanabilmesi için, çalışanlar arası motivasyon, ișbirliği, planlama, yönlendirme, ekipler arası ve ekip içi iletişimi sağlamak için bir lidere gereksinim duyulmaktadir. Profesyonel çalışma hayatında, tüm sektörlerde olduğu gibi inşaat sektöründe de, bir projenin başarılı olmasında, yöneticinin sahip olduğu liderlik özellikleri büyük rol oynamaktadır.

Liderlik en genel tanımıla organize olmuş bir grubu, belirli bir amaç etrafinda toplayabilme ve bu amaçları gerçekleştirmek için onları harekete geçirme, etkileyebilme bilgi ve yeteneklerinin toplamidir.

İnşaat sektöründe ise liderlik, yöneticilerin, çalışanlardan en üst düzeyde performans sağlayabilmek için sergiledikleri tutum ve davranışların bütünü olarak tanımlanmaktadır [19]. Literatürde, inşaat sektöründe liderlik ile ilgili çalışmalar yapan araştırmacılar, yapı üretim sürecinin her farklı aşamasında liderlik stilinin değişmesi gerektiğini ve değiştiğini belirtmişlerdir [15]. Rowlinson ve arkadaşları [20], proje yöneticilerinin fizibilite çalışmaları ve inşaat sözleşmelerinin hazırlanması süreçlerinde sahip 
oldukları destekleyici liderlik stilinin yapım sürecinde yönlendirici liderlik stiline dönüştüğünü belirlemişlerdir. Bresnen [21], İngiltere'de şantiyede çalışan yöneticilerin liderlik stillerini belirlemeye yönelik yaptığ görev yapan yöneticilerin daha çok görev odaklı bir liderlik stiline sahip olduğunu belirlemiştir. Araştırmacı, bununla birlikte liderlik stilleri ile yaş, eğitim, deneyim süresi vb. değişkenler arasında ilişki olmadığını belirtmiştir.

Liderlik, değerlendirilmesi ve ölçülmesi zor bir kavram olması nedeniyle, hangi liderlik stilinin inşaat sektörüne en uygun ve etkin stil olduğu sorusunun cevabı henüz bulunamamıştır. Ancak literatürde, liderlik kavramı pek çok kez tanımlanmış, çok sayıda liderlik teorileri geliştirilmiş ve liderlik stilleri farklı araştırmacılar tarafından farklı şekillerde sınıflandırılmıştır [2227]. Bu çalışma kapsamında ise Bass ve Avolio [25] tarafindan önerilen dönüşümcü ve işlemci liderlik stilleri sınıflaması temel alınmıştır.

\subsection{Dönüşümcü Liderlik}

Burns'e [28] göre dönüşümcü liderlik, izleyicileriyle olumlu aktif bir etkileşime girerek; izleyicilerdeki mevcut enerjiyi bulup örgütsel amaçları doğrultusunda harekete geçirmektedir [29]. Dönüşümcü liderler, örgütlerdeki iş görenlerin çabalarını somut hedefler yerine, bir vizyona yöneltirler. Uzun dönemli bir bakış açısına sahip olan dönüşümcü liderler, astların tüm yetenek ve becerilerini ortaya çıkartıp, kendilerine olan güvenlerini artırarak, onlardan normal olarak beklenenden daha fazla sonuç almayı hedeflemektedirler [30].

Dönüşümcü liderliğin dört alt boyutu vardır; idealleştirilmiş etki, telkinle güdüleme, entelektüel uyarım ve bireysel destektir.

\subsection{1. İdealleştirilmiş Etki}

Karizma olarak da adlandırılır. Liderin etkisi, özellikleri ve davranıșları, izleyenleri tarafından idealleştirilmiştir [31]. Bu nedenle idealleştirilmiş etki, davranış olarak ve atfedilen idealleştirilmiş etki olarak iki ayrı alt boyutta ele alınmaktadır.
İdealleştirilmiş etki karizmadan farklı olarak liderin izleyenleri ile etkileşimde bir vizyon oluşturma ve misyon belirleme davranışlarını içerir [32]. Lidere atfedilen etkiler; liderin astların kendisi ile çalışmaktan gurur duymalarını sağlaması, grubun yararına olacak şeyleri kendi çıkarlarından üstün tutması, izleyenlerin sayg1 duymalarını sağlaması ve kendine güvenen güçlü biri olduğu izlenimini vermesi gibi lidere atfedilen etkileri içerir [32, 33]. İzleyenleri için mükemmel bir rol modeldir. İdealleştirilmiş etkide lider izleyenlerin güven ve saygısını kazanarak örgüt için iyi kararların alınmasını sağlar [34]. İzleyenler, liderin arzu edilen sonuçlara ulaştığını gördüklerinde onun tutum, davranış ve değerlerine özenmeye, onun gibi davranmaya çalışırlar [35]. Davranış alt boyutu; liderin kendisi için önemli değer ve inançlar hakkında konuşması, bir amaç duygusuna sahip olmanın önemini vurgulaması, kararların ahlaki ve etik sonuçlarını dikkate alması ve ortak bir misyon duygusuna sahip olmanın önemini vurgulaması gibi davranışları içerir.

\subsubsection{Telkinle Güdüleme}

Telkinle güdüleme liderin sembol, slogan gibi basit duygusal öğeleri kullanarak astlarında güçlü bir ortak amaç duygusu yaratmasıdır [32]. Diğer bir ifade ile liderin, izleyenleri örgütün vizyonunu benimseme ve örgüte bağlanmaları için güdülemesidir. Böylece lider, izleyenler için moral kaynağı oluşturur. Lider telkinle güdüleme yoluyla, örgütsel amaçlara ulaşmak ve örgütün performansını artırmak için takım ruhunu teşvik eder [36]. Lider izleyenlere moral yükseltici konuşmalar yaparak onların iyimserlik ve coşkularını artırır [36]. Ayrıca geliştirdiği yaratıcı iş metotlarıyla personelin iş yükünü ve görevlerini azaltma yollarını araştırır [35].

\subsubsection{Entelektüel Uyarım}

Entelektüel uyarımcı liderler, izleyenleri problemlere yeni bakış açıları ile bakma konusunda cesaretlendirerek, yaratıcılığ1 desteklerler. Problemlerin altında yatan varsayımları yeniden düşünmeyi ve test etmeyi vurgularlar. Problemlerin çözümünde, mantıklarını kullandıkları gibi, sezgilerini de kullanırlar. Bunun 
sonucunda izleyenler, lider yardımı olmadan da iyi bir problem çözücü ve yenilikçi kişiler olabilirler [36].

\subsubsection{Bireysel Destek}

Dönüşümcü liderler, izleyenlerini, hepsi benzer ve aynı ihtiyaç ve özelliklere sahip bireyler gibi değil, ayrı bir birey ve kişilik olarak görürler. Çalışanları farklı birer kişilik olarak görüp, onları dinlerken aynı zamanda onların kendine olan güvenlerini geliştirmelerini sağlarlar. Lider, burada aynı zamanda bir çeşit danışmanlık rolü oynamaktadır. Danışman olarak lider izleyenlerin güçlü ve zayıf yönlerini görmesine yardım eder. Onların amaçlarına ulaşması için ihtiyaç duydukları kaynaklara ulaşmasına yardım eder. Bireysel destekte anahtar varsayım, her bir çalışanın ihtiyaçlarının farklılığı ve her birinin kendine özgülüğüdür [36].

\section{2. İșlemci Liderlik}

Lider ve iş görenler arasındaki ilişkiler değerli bir şeyin alışverişine dayanır. İşlemci liderlikte basit olarak, lider almak istediği bir şey için izleyicilerine istediklerini vermektedir. Lider, iş görenlere onlardaki belli bir yeteneğin veya becerinin kullanılması amacıyla yaklaşır [30]. Verimliliği artırıcı liderlik tarzı olarak benimsenen işlemci liderlikte, lider; izleyenlere yol gösteren, onları güdüleyen, örgütün amaçlarını, iş görenlerin rollerini ve görevlerini açıkça ortaya koymaya çalışan kişidir [37]. İşlemci liderliğin ise üç alt boyutu vardır. Bunlar sırasıyla koşullu ödül, istisnalarla yönetim ve sınırsız özgürlük alanı yaratan liderdir.

\subsubsection{Koşullu Ödül}

Koşullu ödül boyutunda lider, astları için görevleri ve hedefleri belirler. Astlar hedefleri gerçekleştirdiklerinde alacakları ödülleri bilirler.

\subsection{2. İstisnalarla Yönetim}

Lider yalnızca hatalar ve problemler ortaya çıktığında müdahale eder. "Bozuk değilse dokunma" anlayışı hâkimdir. Liderin birinci amacı, olağan dışı ya da istisna olarak olağan performansın altına düşülen, hata yapılan ve problemlerin olduğu alanları belirlemek ve bunları düzeltmektir. İstisnalarla yönetim "aktif yönetim" ve "pasif yönetim" olmak üzere iki ayrı alt boyutta incelenebilir [25]. Aktif istisnalarla yönetimde, lider, kuralları hataları önlemek için uygular, hataların kayıtlarını tutar ve standartlar yerine sapmalar üzerinde yoğunlaşır. İstisnalarla pasif yönetimde ise, lider, problemler kronikleşinceye kadar müdahale etmez ve hiçbir şekilde çalışanlar ile ilgilenmezler. Liderler, hedeflenen standartlara ulaşılamadığı zaman müdahale ederler. İki alt boyut arasındaki temel fark, pasif formda liderin problemlerin ortaya çıkmasını beklemesi, aktif formda liderin sapmaları aramasidir [25]. İstisnalarla yönetim, kendi kendisini yönetme konusunda gelişmiş iş görenler üzerinde etkin bir yönetim tarzıdır [38].

\subsubsection{Sınırsız Özgürlük Alanı Yaratan Lider (Laissez-faire)}

Sözcük anlamından da anlaşılacağı üzere, iş görenlere sınırsız özgürlük alanı yaratan lider anlamına gelmektedir. Liderin varlığ $\breve{g}_{1}$ ile yokluğu pek belli değildir. Lider, astları kendi hâline bırakır, astlarla bir takas ya da antlaşma yapmaz. Bu durum, özellikle liderlik özelliklerinden yoksun yöneticilerde görülür [32]. Bu liderler, özellikle karar vermekten çekinirler [39].

\section{MATERYAL VE METOT}

\subsection{Materyal}

Çalışmanın örneklemini Türk inşaat sektöründe çalışan mimar ve inşaat mühendisleri oluşturmaktadır. İnşaat sektöründe faaliyet gösteren proje yöneticilerinin liderlik davranışları ve stillerinden, doğrudan ve en çok iş gören mimar ve inşaat mühendisleri etkilendiği için yöneticilerin liderlik davranışını tanımlaması, yorumlaması ve gerçekleşme düzeyini açıklaması gereken çalışan mimar ve inşaat mühendisleridir. $\mathrm{Bu}$ nedenle, Türk inşaat sektöründe iş gören mimar ve inşaat mühendisi olarak faaliyet gösteren 57 katılımcıdan anket yöntemiyle veri toplanmıştır. 


\subsection{Metot}

İnşaat sektörü proje yöneticilerinin liderlik stillerini ölçmek amaciyla Bass ve Avolio [25] tarafından geliştirilen ve Cemaloğlu [40] tarafından Türkçeye uyarlanan "Çok Faktörlü Liderlik Anketi (MLQ-5x) veri toplama arac1 olarak kullanışmıştır. Araştırmacı tarafından anketin kullanım izni www.mindgarden.com adresinden alınmıştır. Online hale getirilen anket, profosyonel bir kuruluş vasıtasıyla Türkiye genelinde ki mimar ve inşaat mühendislerine elektronik posta aracılığıyla ulaştırılmıştır.

Veri toplama aracinda toplam 45 madde bulunmaktadır. $\mathrm{Bu}$ maddelerden dönüşümcü liderlik boyutunda 20, işlemci liderlik boyutunda 16, sonuçlar boyutunda ise 9 madde bulunmaktadır. Araştırma kapsamında dönüşümcü ve işlemci liderlik alt boyutları puanları hesaplanmış, sonuç boyutuna ilişkin veriler değerlendirme kapsamı dişında tutulmuştur. Dönüşümcü liderlik boyutunda; atfedilen idealleştirilmiş etki (4 madde), davranış olarak idealleştirilmiş etki (4 madde), telkinle güdüleme (4 madde), entelektüel uyarım (4 madde), bireysel destek (4 madde); işlemci liderlik boyutunda; koşullu ödül (4 madde), istisnalarla aktif yönetim (4 madde), istisnalarla pasif yönetim (4 madde), laissez-faire liderlik (4 madde) den oluşmaktadır. Anket maddelerini ölçmek için 5'li likert ölçeğinden yararlanılmıştır. Hiçbir zaman (1), Seyrek olarak (2), Bazen (3), Siklıkla (4) ve Her zaman (5) olarak kodlanmıştır.

Verilerin hesaplanması için her alt boyutun toplam puanı alınıp madde sayısına bölünerek aritmetik ortalama değeri bulunmuştur ve tüm hesaplar bu puanlar üzerinden yapılmıştır. Analizlerde SPSS 18 (Statistical Packet Social Sciences) programından yararlanışmıştır.

\subsection{Verilerin Analizi}

Verilerin normal dağılım gösterip göstermediği Kolmogorov-Smirnov testi ile test edilmiş ve bütün değişkenlerin normal dağılım gösterdikleri belirlemiştir. $\mathrm{Bu}$ nedenle ikili grupların karşılaştımasında (cinsiyet) bağımsız örnek t-testi; ikiden fazla grupların karşılaştırılmasında tek yönlü varyans analizi (ANOVA) kullanılmış ve sonuçlar $\mathrm{p}<0,05$ önem düzeyinde test edilmiştir. Liderlik stilerinin belirlenmesi ile ilgili soruların 5'li Likert ölçeğine göre cevaplandırılması nedeniyle sonuçların değerlendirilmesi ve yorumlanmasinda ortalama ve standart sapma değerleri göz önüne alınmıştır. Bu kapsamda katılımcıların cevaplarından ortaya çıkan puanlar $5,00-1,00=4,00$ puanlık bir genişliğe sahiptir. Genişlik 5'e bölünerek yöneticilerin liderlik stilleri aralıkları saptanmış ve Çizelge 1'deki puan aralıkları ve değerlendirme kriterleri kullanılmıştır.

Çizelge 1. 5'li Likert ölçeği sonuçlarını değerlendirme kriterleri

\begin{tabular}{|c|c|c|c|}
\hline $\begin{array}{c}\text { Likert } \\
\text { Ölçeği }\end{array}$ & $\begin{array}{c}\text { Çok } \\
\text { Faktörlü } \\
\text { Liderlik } \\
\text { Anketi }\end{array}$ & $\begin{array}{c}\text { Puan } \\
\text { Aralıkları }\end{array}$ & $\begin{array}{c}\text { Değerlendirme } \\
\text { Kriterleri }\end{array}$ \\
\hline 1 & $\begin{array}{c}\text { Hiçbir } \\
\text { zaman }\end{array}$ & $1,00-1,79$ & $\begin{array}{c}\text { Çok az } \\
\text { düzeyde }\end{array}$ \\
\hline 2 & $\begin{array}{c}\text { Seyrek } \\
\text { olarak }\end{array}$ & $1,80-2,59$ & Az düzeyde \\
\hline 3 & Bazen & $2,60-3,39$ & Orta düzeyde \\
\hline 4 & Sıklıkla & $3,40-4,19$ & $\begin{array}{c}\text { Yüksek } \\
\text { düzeyde }\end{array}$ \\
\hline 5 & Her zaman & $4,20-5,00$ & $\begin{array}{c}\text { Çok yüksek } \\
\text { düzeyde }\end{array}$ \\
\hline
\end{tabular}

\section{BULGULAR}

Bu bölümde öncelikle çalışmada kullanılan "Çok Faktörlü Liderlik Anketinin" güvenilirliği test edilmiş, daha sonra örnekleme ait demografik özellikler, liderlik stillerine ait veriler ve liderlik stilleri ile demografik özellikler arasındaki ilişkilerin sorgulandığı hipotez testi sonuçlarına yer verilmiştir.

\subsection{Anketin Güvenilirlik Analizi}

Çok Faktörlü Liderlik Anketi-Değerlendirme formunun iç tutarlılığını ölçmek amacıyla güvenilirlik analizi uygulanmıştır. Her alt boyutun 
Cronbach Alpha Katsayıları Çizelge 2'de verilmiştir. Cronbach Alpha değerlerinin 0,8'in üzerinde olması, anketin yüksek derecede güvenilir olduğunu göstermektedir [41].

Çizelge 2. Çok faktörlü liderlik anketi Cronbach Alpha değerleri

\begin{tabular}{|c|c|}
\hline Liderlik Stilleri & $\begin{array}{c}\text { Cronbach } \\
\text { Alpha }\end{array}$ \\
\hline \multicolumn{2}{|l|}{ Dönüşümcü liderlik } \\
\hline Davranış olarak idealleştirilmiş etki & 0,881 \\
\hline Atfedilen idealleştirilmiş etki & 0,881 \\
\hline Telkinle güdüleme & 0,880 \\
\hline Entelektüel uyarım & 0,887 \\
\hline Bireysel destek & 0,883 \\
\hline \multicolumn{2}{|l|}{ İşlemci liderlik } \\
\hline Koşullu ödül & 0,884 \\
\hline İstisnalarla aktif yönetim & 0,903 \\
\hline İstisnalarla pasif yönetim & 0,912 \\
\hline Laissez-faire liderlik & 0,940 \\
\hline
\end{tabular}

\subsection{Katılımeıların Demografik Özellikleri}

Katılımcıların cinsiyet, meslek, eğitim durumu, mevcut işlerinde çalışma süreleri ve inşaat sektöründeki toplam deneyim süreleri ile ilgili sorulara verilen cevapların dağılımı Çizelge 3 'de özetlenmiştir.

Çizelge 3 incelendiğinde katılımcıların büyük çoğunluğunun $\quad(\% 68,4) \quad$ erkek olduğu görülmektedir. $\mathrm{Bu}$ durumun, inşaat sektöründe erkek cinsiyetin çoğunlukta olmasından kaynaklandığı düşünülmektedir. Katılımcılar mesleki durumlarına göre incelendiğinde araştırmaya katılan mimar ve inşaat mühendislerinin sayısının ve yüzdelerinin $(\% 52,6$ ve $\% 47,4)$ birbirine çok yakın olduğu diğer bir ifade ile dengeli bir dağılım gösterdiği belirlenmiştir. Katılımcıların eğitim durumlarına göre dağılımı incelendiğinde, büyük çoğunluğunun $(\% 68,4)$ lisans derecesine sahip olduğu belirlenmiştir. Araştırmaya katılan mimar ve inşaat mühendislerinin inşaat sektöründeki toplam deneyim süresi incelendiğinde ise katılımcıların büyük çoğunluğunun $(\% 28,1+\% 38,6=\% 66,7) 11$ y1l ve üzeri deneyime sahip mimar ve inşaat mühendislerinden oluştuğu görülmektedir. Diğer bir ifade ile araştırma katılımcıları deneyimli mimar ve mühendislerden oluşmaktadır (Çizelge $3)$.

Çizelge 3. Katılımcıların demografik özellikleri

\begin{tabular}{|c|c|c|}
\hline Demografik Özellikler & Frekans (f) & $\begin{array}{c}\text { Yüzde } \\
(\%)\end{array}$ \\
\hline \multicolumn{3}{|l|}{ Cinsiyet } \\
\hline Kadın & 18 & 68,4 \\
\hline Erkek & 39 & 31,6 \\
\hline \multicolumn{3}{|l|}{ Meslek } \\
\hline Mimar & 27 & 47,4 \\
\hline İnşaat Mühendisi & 30 & 52,6 \\
\hline \multicolumn{3}{|l|}{ Eğitim Düzeyi } \\
\hline Lisans & 39 & 68,4 \\
\hline Yüksek lisans & 18 & 31,6 \\
\hline Doktora & - & - \\
\hline \multicolumn{3}{|c|}{ İnşaat sektöründe toplam deneyim süresi } \\
\hline $1-5 \mathrm{y} 1 \mathrm{l}$ & 7 & 12,3 \\
\hline $6-10$ y1l & 12 & 21,0 \\
\hline $11-15 \mathrm{y} 1 \mathrm{l}$ & 16 & 28,1 \\
\hline 16 yıl ve üzeri & 22 & 38,6 \\
\hline
\end{tabular}

\subsection{Türk İnşaat Sektörü Yöneticilerinin Liderlik Stilleri}

Proje yöneticilerin kendileri ile ilgili tarafsız bir değerlendirme yapamayacakları düşünülerek, iş gören mimar ve inşaat mühendislerin yöneticilerinin liderlik stillerine dair algılarının ne yönde olduğu Çizelge 4'de araştırılmıştır. Bu kapsamda Çok Faktörlü Liderlik anketi ile elde edilen verilerin ortalaması ve standart sapmaları dikkate alınarak değerlendirmeler yapılmıştır (Çizelge 4). 
Çizelge 4. Çalışanların, proje yöneticilerinin liderlik stillerine ilişkin görüşleri

\begin{tabular}{|c|c|c|}
\hline Liderlik Stilleri & $\bar{x}$ & S \\
\hline \multicolumn{3}{|l|}{ Dönüşümcü liderlik } \\
\hline Davranış olarak idealleştirilmiş etki & 4,14 & 0,74 \\
\hline Atfedilen idealleştirilmiş etki & 3,99 & 0,81 \\
\hline Telkinle güdüleme & 4,01 & 0,79 \\
\hline Entelektüel uyarım & 4,13 & 0,66 \\
\hline Bireysel destek & 4,07 & 0,81 \\
\hline \multicolumn{3}{|l|}{ İşlemci liderlik } \\
\hline Koşullu ödül & 4,00 & 0,71 \\
\hline İstisnalarla aktif yönetim & 3,21 & 0,83 \\
\hline İstisnalarla pasif yönetim & 2,82 & 0,65 \\
\hline Laissez-faire liderlik & 1,54 & 0,73 \\
\hline
\end{tabular}

Çizelge 4 incelendiğinde, iş gören mimar ve inşaat mühendisleri, yöneticilerinin liderlik stilini dönüşümcü liderlik olarak belirtmektedirler. Liderlik stillerinin alt boyutları incelendiğinde ise katılımcılar yöneticilerin en fazla $\bar{x}=4,14$ yüksek düzeyde "davranış olarak idealleştirilmiş etki", en az $\bar{x}=1,54$ çok az düzeyde "laissez-faire" boyutlarını gerçekleştirdikleri görülmektedir. Diğer bir ifade ile çalışan mimar ve inşaat mühendisleri, ağırlıklı olarak, proje yöneticilerinin liderlik özelliklerini; çalışanlarına saygı gösteren ve onlar için çok iyi bir rol model olan; aynı zamanda çalışanların örgütsel misyona inanmalarını sağlayan özellikler şeklinde tanımlamışlardır. En homojen değerlendirme "entelektüel uyarım" $(S=0,66)$ en heterojen değerlendirme ise doyum $(S=0,94)$ alt boyutundadir.

\subsection{Proje Yöneticilerinin Liderlik Stilleri ile Çeşitli Değişkenler Arası Hipotez Testleri}

İş gören mimar ve inşaat mühendislerinin proje yöneticilerinin liderlik stillerine ilişkin algılarının cinsiyete göre değişip değişmediği bağımsız örnek t-test kullanılarak araştırılmıştır (Çizelge 5).

Çizelge 5. Çalışanların, proje yöneticilerinin liderlik stillerine ilişkin algılarının cinsiyetlerine göre dağılımı

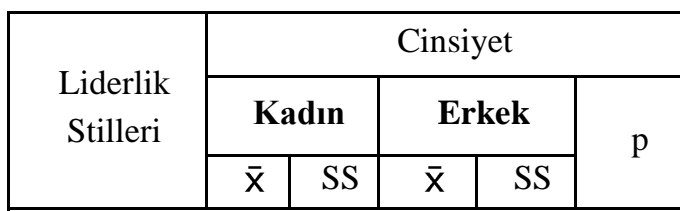

\section{Dönüşümcü liderlik}

\begin{tabular}{|l|c|c|c|c|c|}
\hline $\begin{array}{l}\text { Davranış } \\
\text { olarak } \\
\text { idealleştiril } \\
\text { miş etki }\end{array}$ & 4,11 & 0,75 & 4,15 & 0,74 & 0,766 \\
\hline $\begin{array}{l}\text { Atfedilen } \\
\text { idealleştiril } \\
\text { miş etki }\end{array}$ & 3,92 & 0,85 & 4,01 & 0,81 & 0,616 \\
\hline $\begin{array}{l}\text { Telkinle } \\
\text { güdüleme }\end{array}$ & 4,08 & 0,71 & 4,00 & 0,83 & 0,611 \\
\hline $\begin{array}{l}\text { Entelektüel } \\
\text { uyarım }\end{array}$ & 4,16 & 0,62 & 4,12 & 0,68 & 0,792 \\
\hline $\begin{array}{l}\text { Bireysel } \\
\text { destek }\end{array}$ & 4,26 & 0,85 & 4,01 & 0,80 & 0,164 \\
\hline İşlemci liderlik & 3,89 & 0,67 & 4,03 & 0,73 & 0,355 \\
\hline $\begin{array}{l}\text { Koşullu } \\
\text { ödül }\end{array}$ & 3,06 & 0,68 & 3,25 & 0,87 & 0,298 \\
\hline $\begin{array}{l}\text { İstisnalarla } \\
\text { aktif } \\
\text { yönetim }\end{array}$ & 1,42 & 0,43 & 1,58 & 0,81 & 0,335 \\
\hline $\begin{array}{l}\text { İstisnalarla } \\
\text { pasif } \\
\text { yönetim }\end{array}$ & 0,60 & 2,90 & 0,64 & $0,008^{*}$ \\
\hline $\begin{array}{l}\text { Laissez- } \\
\text { faire liderlik }\end{array}$ & & \multicolumn{5}{|l|}{} & & \\
\hline
\end{tabular}


Çalışanların, proje yöneticilerinin liderlik stillerine ilişkin algıları cinsiyete göre incelendiğinde, istisnalarla pasif yönetim $(\mathrm{p}<0,05$ olduğu için) boyutunda cinsiyete göre anlamlı bir farklılık olduğu görülmektedir. İstisnalarla pasif yönetim liderlik stilinin algılanması, erkek iş görenler $(\overline{\mathrm{X}}=2,90)$, ve kadın iș görenler arasında $(\overline{\mathrm{X}}=2,53)$ farklılık göstermektedir. Diğer bir ifade ile erkek mimar ve inşaat mühendisleri, proje yöneticilerinin problemler kronikleşinceye kadar müdahale etmemektedir düşüncesini kadın iş görenlere göre daha fazla yaşamaktadırlar. Diğer liderlik stillerinin algılanması ise cinsiyete göre değişmemektedir (Çizelge 5).

Çalışanların, proje yöneticilerinin liderlik stillerine ilişkin algıları mesleki duruma göre incelendiğinde, atfedilen idealleştirilmiş etki ve istisnalarla pasif yönetim $(p<0,05$ olduğu için) boyutlarında anlamlı bir farklılık olduğu görülmektedir. Diğer bir ifade ile proje yöneticilerinin liderlik stillerinin algısı mesleki duruma göre değişmektedir. İnşaat sektöründe mimarlar inşaat mühendislerine göre $(\overline{\mathrm{X}}=4,16$; $\overline{\mathrm{X}}=3,84$ ) proje yöneticilerinin atfedilen idealleştirilmiş etki liderlik stilini daha fazla gerçekleştirdiklerini ileri sürmektedir. Buna karşın, inşaat mühendisleri ise mimarlara göre $(\bar{X}=2,94$; $\overline{\mathrm{X}}=2,67$ ) proje yöneticilerinin istisnalarla pasif yönetim liderlik stilini daha fazla gerçekleştirdiklerini düşünmektedirler (Çizelge 6).

İnşaat sektöründe çalışanların, proje yöneticilerinin liderlik stillerine göre ilişkin algıları sektördeki deneyim sürelerine göre incelendiğinde ise; davranış olarak idealleştirilmiş etki, atfedilen idealleştirilmiş etki, telkinle güdüleme, bireysel destek, entelektüel uyarım, koşullu ödül ve istisnalarla aktif yönetim $(\mathrm{p}<0,05)$ boyutlarında çalışanların deneyim sürelerine göre anlamlı bir farklılık olduğu görülmektedir (Çizelge 7). Çalışanların deneyim sürelerine göre, farklılığın hangi gruplar arasında olduğunu saptamak için yapılan Scheffe testinin sonuçlarına göre 1-5 yıl deneyime sahip olan çalışanlar, 16 yıl ve daha fazla deneyime sahip olan çalışanlara göre proje yöneticilerinin davranış olarak idealleştirilmiş etki, atfedilen idealleştirilmiş etki, telkinle güdüleme, entelektüel uyarım, koşullu ödül ve istisnalarla aktif yönetim boyutlarında liderlik özelliklerini ve davranışlarını yerine getirmede daha başarısız olduklarını düşünmektedirler. Koşullu ödül alt boyutunda buna ek olarak deneyim süresi 11-15 y1l olanlarla, 16 yıldan fazla deneyime sahip olanlar arasında da önemli derecede ortalama farklılıkları mevcuttur (Çizelge 7).

Çizelge 6. Çalışanların, proje yöneticilerinin liderlik stillerine ilişkin algılarının mesleklerine göre dağılımı

\begin{tabular}{|c|c|c|c|c|c|}
\hline \multirow{3}{*}{$\begin{array}{c}\text { Liderlik } \\
\text { Stilleri }\end{array}$} & \multicolumn{5}{|c|}{ Meslek } \\
\hline & \multicolumn{2}{|c|}{ Mimar } & \multicolumn{2}{|c|}{$\begin{array}{c}\text { İnşaat } \\
\text { Mühendisi }\end{array}$} & \multirow{2}{*}{$\mathrm{p}$} \\
\hline & $\bar{x}$ & SS & $\bar{x}$ & SS & \\
\hline \multicolumn{6}{|c|}{ Dönüşümcü liderlik } \\
\hline $\begin{array}{l}\text { Davranış } \\
\text { olarak } \\
\text { idealleştirilm } \\
\text { iş etki }\end{array}$ & 4,11 & 0,70 & 4,18 & 0,76 & 0,658 \\
\hline $\begin{array}{l}\text { Atfedilen } \\
\text { idealleştirilm } \\
\text { iş etki }\end{array}$ & 4,16 & 0,82 & 3,84 & 0,73 & $0,037^{*}$ \\
\hline $\begin{array}{l}\text { Telkinle } \\
\text { güdüleme }\end{array}$ & 3,94 & 0,77 & 4,12 & 0,75 & 0,200 \\
\hline $\begin{array}{l}\text { Entelektüel } \\
\text { uyarım }\end{array}$ & 4,19 & 0,62 & 4,11 & 0,66 & 0,513 \\
\hline $\begin{array}{l}\text { Bireysel } \\
\text { destek }\end{array}$ & 4,16 & 0,79 & 4,02 & 0,78 & 0,350 \\
\hline \multicolumn{6}{|c|}{ İşlemci liderlik } \\
\hline Koşullu ödül & 3,98 & 0,69 & 4,06 & 0,70 & 0,532 \\
\hline $\begin{array}{l}\text { İstisnalarla } \\
\text { aktif yönetim }\end{array}$ & 3,11 & 0,75 & 3,28 & 0,90 & 0,284 \\
\hline $\begin{array}{l}\text { İstisnalarla } \\
\text { pasif } \\
\text { yönetim }\end{array}$ & 2,67 & 0,62 & 2,94 & 0,67 & $\mathbf{0 , 0 3 1}{ }^{*}$ \\
\hline $\begin{array}{l}\text { Laissez-faire } \\
\text { liderlik }\end{array}$ & 1,51 & 0,55 & 1,54 & 0,81 & 0,840 \\
\hline
\end{tabular}

${ }^{*} \mathrm{p}<0,05$ 
Çizelge 7. Çalışanların, proje yöneticilerinin liderlik stillerine ilişkin algılarının inşaat sektöründe deneyim sürelerine göre dağılımı

\begin{tabular}{|c|c|c|c|}
\hline Liderlik Stilleri & $\mathrm{F}$ & $\mathrm{p}$ & $\begin{array}{c}\text { Scheffe } \\
\text { Testi }\end{array}$ \\
\hline \multicolumn{4}{|c|}{ Dönüşümcü Liderlik } \\
\hline $\begin{array}{l}\text { Davranış olarak } \\
\text { idealleştirilmiş } \\
\text { etki }\end{array}$ & 3,43 & $0,020 *$ & A-D \\
\hline $\begin{array}{l}\text { Atfedilen } \\
\text { idealleştirilmiş } \\
\text { etki }\end{array}$ & 4,08 & $0,009 *$ & A-D \\
\hline $\begin{array}{l}\text { Telkinle } \\
\text { güdüleme }\end{array}$ & 3,32 & $0,023^{*}$ & A-D \\
\hline $\begin{array}{l}\text { Entelektüel } \\
\text { uyarım }\end{array}$ & 5,55 & $0,001 *$ & A-D \\
\hline Bireysel destek & 5,65 & $0,001 *$ & A-D \\
\hline \multicolumn{4}{|l|}{ İşlemci Liderlik } \\
\hline Koşullu ödül & 4,82 & $0,003 *$ & $\begin{array}{l}\text { A-D, } \\
\text { C-D }\end{array}$ \\
\hline $\begin{array}{ll}\text { İstisnalarla } & \text { aktif } \\
\text { yönetim } & \end{array}$ & 2,75 & $0,046^{*}$ & A-D \\
\hline $\begin{array}{ll}\text { İstisnalarla pasif } \\
\text { yönetim }\end{array}$ & 0,87 & 0,459 & - \\
\hline $\begin{array}{l}\text { Laissez-faire } \\
\text { liderlik }\end{array}$ & 2,44 & 0,068 & - \\
\hline
\end{tabular}

${ }^{*} \mathrm{p}<0,05 \mathrm{~A}=1-5$ yıl $\mathrm{B}=6-10$ yıl $\mathrm{C}=11-15$ y1l $\mathrm{D}=16$ yıl ve üzeri

\section{TARTIŞMA}

Çalışmanın birinci problemine ilişkin sonuçlar araştırma kapsamında görüşlerine başvurulan mimar ve inşaat mühendislerinin proje yöneticilerinin dönüşümcü liderlik stilini işlemci liderliğe göre daha fazla gerçekleştirdiklerini göstermektedir. $\mathrm{Bu}$ bulgu Limsala ve Ogunlana'nın [18] ve Opuku ve arkadaşlarının [42] araştırma bulgularıyla tutarlıdır.
Dönüşümcü liderlik stilinin davranış olarak idealleştirilmiş etki alt boyutunun gerçekleşme düzeyinin yüksek olması beklentilere uygundur. $\mathrm{Bu}$ durum, inşaat sektöründe faaliyet gösteren proje yöneticilerinin her birinin kendi bulunduğu çalışma ortamında ortak bir misyona sahip olduklarının ve verdikleri kararların etik sonuçlarını dikkate aldıklarının bir göstergesidir. İşlemci liderlik stilinin koşullu alt boyutunun gerçekleşme düzeyinin yüksek olması da dikkate çekici bir noktadır. Proje yöneticilerinin amaçlarını açıklamaları, iş gören mimar ve inşaat mühendislerinin alacakları ödüllerin baştan belirtmeleri Türk inşaat sektöründe olması beklenen bir davranış örüntüsüdür.

İşlemci liderliğin en az gerçekleşen alt boyutunun laissez-faire liderlik olması da beklentilere uygundur. "Laissez-faire" kararları erteleyen, ödülleri sağlayamayan ve astları motive etmek için hiçbir girişimde bulunamayan, liderlik özelliklerinin yoksun yöneticilerde görülmektedir. İnşaat sektörü liderin sözde var olduğu bir liderlik biçimini onaylamaz. Liderlik stillerinin alt boyutlarına dair elde edilen bulgular Limsala ve Ogunlana'nın [18] bulguları ile kısmen tutarlıdır. Tayland inşaat sektöründe dönüşümcü liderlik stilinin telkinle güdüleme alt boyutunun en yüksek düzeyde gerçekleşmesi [18]bu çalışmanın sonucuyla çelişmekteyken, en az gerçekleşen alt boyutun laissez-faire olması ise bu çalışma sonucuyla örtüşmektedir.

İkinci araştırma konusu olarak, proje yöneticilerinin liderlik stillerini gerçekleştirme düzeyleri, iş görenlerin cinsiyetlerine göre incelenmiştir. Erkek mimar ve inşaat mühendisi çalışanlar; istisnalarla pasif yönetim alt boyutunu kadın mimar ve inşaat mühendislerine göre proje yöneticilerinin daha fazla gerçekleştirdiklerini düşünmektedirler. Diğer bir ifade ile erkek mimar ve mühendisler yöneticilerinin sorunlarla yeterince ilgilenmediklerini, ancak hedeflenen amaçlara ulaşılamadığı zaman sorunlara müdahale etmeyi, kadın iş görenlere göre daha yüksek düzeyde düşünmektedirler. İnşaat sektöründe çalışanların kadın ya da erkek olmaları, onların yöneticilerinin liderlik stillerine ilişkin algılarını doğrudan ve dolaylı olarak etkilemektedir [40]. Bu durumun 
kadın ve erkek işgörenlerin kişilik ve değer farklılıklarından kaynaklandığı düşünülmektedir. Mamaş [43]'ın çalışma bulguları çalışmanın bu bulgusu ile ters düşmektedir. Mamaş’a göre [43] kadın yöneticilerin istisnalarla pasif yönetim davranışı erkeklere göre daha ileri düzeydedir. Her iki çalışmanın da Türkiye'de gerçekleştirilmesine ve hemen hemen aynı katılıme sayısına sahip olmasına rağmen aynı kavram ile ilgili sonuçların tamamen zit olmasının nedeninin örneklem farklılığından kaynaklandığı düşünülmektedir. Mamaş'ın [43] çalışmasında yöneticilerin liderlik stillerini değerlendiren örneklem grubu orta ve üst düzey yöneticilerden oluşurken bu çalışmada proje yöneticilerin liderlik stillerini işgören mimar ve mühendisler değerlendirmiştir. Literatürde, liderlik stillerinin cinsiyete göre değişip değişmediğini araştıran pek çok çalışma mevcut olsa da, inşaat sektöründe bu konuya yönelik bulgu oldukça azdır [15, 44, 45]. Mevcut çalışmaların bazıları liderlik stilinin cinsiyete göre değiştiğini ileri sürerken bazıları ise cinsiyetten bağımsız olduğunu göstermektedir [46]. Giritli ve Oraz [15] da Türk inşaat sektörü yöneticilerinin liderlik stillerini belirlemeye yönelik yaptıkları çalışmada liderlik stilinin cinsiyete göre farklılaştıklarını belirtmişlerdir.

İnşaat sektörü proje yöneticilerinin liderlik stillerini gerçekleştirme düzeyleri işgörenlerin mesleklerine incelenmiştir. Sektörde inşaat mühendisi olarak iş görenler, yöneticilerinin sorunlarla yeterince ilgilenmediklerini, ancak hedeflenen amaçlara ulaşılamadığı zaman sorunlara müdahale ettiğini, mimar çalışanlara göre daha yüksek düzeyde düşünmektedirler. Buna karşın mimar çalışanlar inşaat mühendislerine göre daha yüksek düzeyde, yöneticileri ile çalışmaktan gurur duymakta, grubun yararına olacak şeyleri yöneticilerinin kendi çıkarlarından daha üstün tuttuğunu düşünmektedirler. $\mathrm{Bu}$ farklılığın, mesleki kültür farklılıklarından kaynaklandığ düşünülmektedir. Bu bulgu Mamaş'ın [43] yaptığı çalışmanın sonuçları ile kısmen örtüşmektedir. Mamaş [43] çalışmasında inşaat mühendislerinin laissez-faire tipi liderlik davranışını mimarlara göre daha çok tercih ettiklerini; mimarların ise davranış olarak idealleştirilmiş etki liderlik stilini inşaat mühendislerine göre daha fazla tercih ettiklerini belirlemiştir. Son olarak inşaat sektörü proje yöneticilerinin liderlik stillerini gerçekleştirme düzeyleri işgören mimar ve inşaat mühendislerinin inşaat sektöründeki deneyim sürelerine göre dağılımı incelenmiştir. İnşaat sektöründeki deneyim süresi ile davranış olarak idealleştirilmiş etki, atfedilen idealleştirilmiş etki, telkinle güdüleme, entelektüel uyarım, bireysel destek, koşullu ödül ve istisnalarla aktif yönetim liderlik stilleri arasında anlamlı bir ilişkinin olduğu kabul edilmiştir. Mamaş [43]'ın çalışmasında da idealleştirilmiş etki, telkinle güdüleme ve bireysel destek liderlik davranışları ile inşaat sektöründeki deneyim süresi arasında anlamlı ilişkiler bulunmuştur.

\section{SONUÇLAR VE ÖNERILER}

$\mathrm{Bu}$ çalışmada, Türk inşaat sektörü proje yöneticilerinin liderlik stilleri belirlenerek, liderlik stilleri ile cinsiyet, meslek ve inşaat sektöründeki deneyim süresi değişkenleri arasındaki ilişkilerin incelenmesi esas alınmıştır. Bu kapsamda proje yöneticilerinin liderlik stillerini belirleyebilmek için inşaat sektöründe iş gören pozisyonunda çalışan 57 adet mimar ve inşaat mühendisinin görüșüne başvurulmuștur. Elde edilen veriler ile aşağıdaki sonuçlara ulaşılmıştır:

- İşgören mimar ve inşaat mühendisleri proje yöneticilerinin liderlik stilini yüksek düzeyde "davranış olarak idealleştirilmiş etki", çok az düzeyde "Laissez-faire" olarak tanımlamaktadır. $\mathrm{Bu}$ durum, yöneticilerin çalışanlarının fikirlerine saygı duyan, kararlarını alırken ahlaki ve etik sonuçları dikkate alan, çalışanları tarafından rol model olarak alınan etkin ve güçlü birer lider olduklarının göstergesidir.

- Erkek mimar ve inşaat mühendisleri kadın çalışanlara göre, proje yöneticilerinin istisnalarla pasif yönetim liderlik stilini daha fazla gerçekleştirdiklerini düşünmektedirler.

- Mimar işgörenler, inşaat mühendislerine göre proje yöneticilerinin atfedilen idealleştirilmiş etki alt boyutunu daha fazla gerçekleştirdiklerini düşünürken; inşaat mühendisi çalışanlar mimarlara göre 
istisnalarla pasif yönetim alt boyutunu daha çok gerçekleştirdiklerini algılamaktadırlar.

- 1-5 yıl deneyime sahip olan çalışanlar, 16 yıl ve daha fazla deneyime sahip olan çalışanlara göre proje yöneticilerinin davranış olarak idealleştirilmiş etki, atfedilen idealleştirilmiş etki, telkinle güdüleme, entelektüel uyarım, koşullu ödül ve istisnalarla aktif yönetim boyutlarında liderlik özelliklerini ve davranışlarını yerine getirmede daha başarısız olduklarını düşünmektedirler.

$\mathrm{Bu}$ çalışmanın sonuçları da göstermektedir ki, Türk inşaat sektöründe iş gören mimar ve inşaat mühendisleri yaygın bir şekilde proke yöneticilerinin etkin birer lider olduğunu düşünmektedirler. Bununla birlikte, cinsiyet, meslek ve inşaat sektöründeki deneyim süresine göre liderlik stillerinin algılanması, işgörenler arasında farklılık gösterebilmektedir. Belirtilen nedenlerle lider hitap ettiği grubun yapısına, kültür seviyesi, yaş ve deneyimlerine göre liderlik davranışlarını belirlemek durumundadır [47].

$\mathrm{Bu}$ çerçevede, yöneticilere liderlik eğitimleri verilmesi ve bu eğitimler sürecine yukarıda belirtilen değişkenlere göre yöneticilerin belirli stratejiler geliştirmeleri önerilmektedir.

\section{KAYNAKLAR}

1. Eren, E., 1991. Yönetim ve Organizasyon, 1. Bask1, İstanbul Üniversitesi İşletme Fakültesi Yayınları, İstanbul, Türkiye.

2. Ataman, G., 2002. İşletme Yönetimi, 2. Bask1, Türkmen Kitabevi, İstanbul, Türkiye.

3. McShane, S. L., Von Glinow, M. A., 2000. Organizational Behaviour, 1st Ed. McGrawHill, New York, USA.

4. Hyatt, L., Hyatt, B., Hyatt, J., 2007. Effective Leadership Through Emotional Maturity, Academic Leadership, 5(2).

5. Harvey, R.C., Ashworth, A., 1993. The Construction Industry of Great Britain, Butterworth-Heinemann.

6. Morrison, R. S., Jones, L., Fuller, B., 1997. The Relation Between Leadership Style and Emprowement on Job Satisfaction of Nurses,
Journal of Nursing Administration, 22, 5, 2734.

7. Chen, H., Beck, S. L., Amos, L. K., 2005. Leadership Styles and Nursing Faculty Job Satisfaction in Taiwan, Journal of Nursing Scholarship, 34, 4, 374-380.

8. Ardichvili, A., Kuchinke, K. P., 2002. Leadership Styles and Cultural Values Among Managers and Subordinates: A Comparative Study of Four Countries of the Former Soviet Union, Germany, and the US, Human Resource Development International, 5, 1, 99-117.

9. Boonyachai, Y., 2011. An Investigation of the Leardership Styles of Middle Managers in the Thai Hotel Industry Using the MLQ (5X-Short Form) and Hofstede's Cultural Dimensions, Doctorate of Business Administration, Southern Corss University, Australia.

10.Bresnen, M. J., 1990. Organising Construction, Project Organisation and Matrix Management, Routledge, London.

11.Loosemore, M., Dainty, A.R.J., Lingard, H. 2003. Human Resource Management in Construction Projects, Strategic and Operational Approaches, Spon Press, London.

12.Wild, A., 2002. The Unmanageability of Construction and the Theoretical Psycho-Social Dynamics of Projects", Engineering, Construction and ArchitecturalManagement, 9, 4, 345-351.

13.Druker, J., White, G., 1995. Misunderstood and Undervalued? Personnel Management in Construction", Human Resource Management Journal, 5, 3, 77-91.

14.Fellows, R., Langford, D., Newcombe, R. ve Urry, S. 2002. Construction Management in Practice, Blackwell Science, Oxford.

15.Giritli, H., Oraz, G.T., 2004. Leadership Styles: Some Evidence from the Turkish Construction Industry, Constuction Management and Economics, 22, 3, 253-262.

16.Fellows, R., Langford, D., Newcombe, R., Urry, S. 2002. Construction Management in Practice, Blackwell Science, Oxford.

17.Dulaimi, M., 2005. The Influence of Academic Education and Formal Training on the Project Manager's Behavior, Journal of Construction Research, 6, 1, 179-193. 
18.Limsila, K., Ogunlana, S.O. 2008. Performance and Leadership Outcome Correlates of Leadership Styles and Subordinate Commitment, Engineering, Construction and Architectural Management, 15, 2, 164-184.

19.Walker, A., 1996. Project Management in Construction, 3rd Ed., Blackwell Science.

20.Rowlinson S. and Cheung T., 1993. Leadership Style of Construction Managers in Hong Kong, Construction Management and Economics, 11, 455-465.

21.Bresnen, M.J., Bryman, A.E., Ford, J.R., Beardsworth, A.D., Keil, E.T., 1986. The Leader Orientation of Construction Site Managers, ASCE Journal of Construction Engineering and Management, 112, 370-86.

22.Tannenbaum, R. ve Schmidt, W.H., 1973. How to Choose a Leadership Pattern. Harvard Business Review, May-June, 162-75, 178-80.

23.Hersey. P., Blanchard, K.H., 1982. Management of Organizational Behaviour, 4th edn, Prentice-Hall, Englewood, Cliffs, NJ.

24.Handy, C., 1993. Understanding Organizations, Penguin Books, London.

25.Bass, Bernard. M., B. J. Avolio., 1995. MLQ Multifactor Leadership Questionnaire, CA: Mind Garden, Palo

26.Mullins, L., 1999. Management and Organizational Behaviour, 6th edn, Pitman, London.

27.Vecchio, R.P., 2002. Preferences for Idealised Styles of Supervision, the Leadership Quarterly, 13,6, 643-71.

28.Burns, J. M., 1978. Leadership. NewYork: Harper ve Row.

29. Krishnan, R. V., 2001. Value Systems of Transformational Leaders, Leadership and Organizational Development Journal, 22, 3,126-131

30.Tabak, A., 2005. Lider ve Takipçileri. Ankara: Asil Yayın Dağıtım.

31.Güney, S., 2000. Yönetim ve Organizasyon El Kitab1. Ankara: Nobel.

32.Karip, E., 1998. Dönüşümcü Liderlik, Kuram ve Uygulamada Eğitim Yönetimi. 16, 443-465

33.Açıkalın, A., 2000. İlkögretim Okulu Yöneticilerinin Dönüsümcü Liderlik Özellikleri ve Empati Becerileri Arasındaki İliski. Ankara İli Örnegi. Yayımlanmamıs
Yüksek Lisans Tezi. Ankara: G. Ü. Egitim Bilimler Enstitüsü.

34.Hall, J., Johnson, S., Wysocki, A., Kepner, K., 2002. Transformational Leadership the Transformation of Managers and Associates. http://edis.ifas.ufl.edu/pdffiles/HR/HR02000.p df 26.01.2016 tarihinde erişildi.

35.Avolio, B.J.,. Waldman, D.A., Yammarino, J., 1991. Leading in the 1990s: The Four I's Transformational Leadership, Journal of European Industrial Training. 15 (4), 9-16.

36.Bass, B.M., 1990. From Transactional to Transformational Leadership: Leadership to Share the Vision, Organizational Dynamics, 18(3), 19-32.

37.Bateman, T. S., 2002. Management: Competing in The New Era. Boston: McgrawHill Irwin.

38.Hartog, D. N., Muijen, J. V., Koopman, P. L., 1997. Transactional Versus Transformational Leadership: An Analysis of the MLQ, Journal of Occupational and Organizational Psychology, 70, 19-34.

39.Çelik, V. , 1998. Eğitimde Dönüşümcü Liderlik, Kuram ve Uygulamada Eğitim Yönetimi, 16, 423-442.

40.Cemaloğlu, N., 2007. Okul Yöneticilerinin Liderlik Stilleri ile Yıldırma Arasındaki İlişki, Hacettepe Üniversitesi Eğitim Fakültesi Dergisi. 33, 77-87.

41.Kalaycı, Ş., 2008. SPSS Uygulamalı, Çok Değişkenli, İstatistik Teknikleri, Asil Yayın Dağıtım, Ankara.

42.Opuku, A., Ahmed, V., Cruickshank, H., 2015. Leadership Styles of Sustainability Professionals in the UK Construction Industry, Built Environment Project and Asset Management, 5, 2, 184-201.

43.Mamaş, G., 2015. Türk İnşaat Proje Yönetimi Sektöründe Çalışan Üst ve Orta Düzey Yöneticilerin Dönüşümcü Liderlik Davranışları Üzerine Bir Araştırma, İstanbul Teknik Üniversitesi, Fen Bilimleri Enstitüsü, Yüksek Lisans Tezi, İstanbul.

44.Gale, A., 1994. Women in Non-Traditional Occupations: The Construction Industry. Women in Management Review, 9, 2, 3-14.

45.Bennet, J.F., Davidson, M.J., Gale, A.W., 1999. Women in Construction: A Comparative 
Investigation into the Expectations and Experiences of Female and Male Construction Undergraduates And Employees. Women in Management Review, 14, 7, 273-91.

46.Epstein, C.F., 1991. Letter to Editor. Harvard Business Review, 69, 1, 150-1.

47.Eren, E., 1998. Örgütsel Davranıs ve Yönetim Psikolojisi. İstanbul: Beta. 
